University of Rhode Island

DigitalCommons@URI

Open Access Master's Theses

2012

\title{
Locus of Control, Decision Making, and Economic Stress
}

Stephen Favasuli

University of Rhode Island

Follow this and additional works at: https://digitalcommons.uri.edu/theses

\section{Recommended Citation}

Favasuli, Stephen, "Locus of Control, Decision Making, and Economic Stress" (2012). Open Access

Master's Theses. Paper 1605.

https://digitalcommons.uri.edu/theses/1605

This Thesis is brought to you for free and open access by DigitalCommons@URI. It has been accepted for inclusion in Open Access Master's Theses by an authorized administrator of DigitalCommons@URI. For more information, please contact digitalcommons-group@uri.edu. 
LOCUS OF CONTROL, DECISION MAKING, AND ECONOMIC STRESS

BY

STEPHEN FAVASULI

A THESIS SUBMITTED IN PARTIAL FULFILLMENT OF THE REQUIREMENTS FOR THE DEGREE OF MASTER OF ARTS

IN PSYCHOLOGY 


\begin{abstract}
Economic stress is associated with a number of adverse psychological, academic and health outcomes. This study investigated the relationship between locus of control and decision making styles in accounting for variation in economic stress among lowincome participants. Mothers of preschool children attending day care centers in low income areas completed surveys on locus of control, five decision making styles, and economic stress. It was hypothesized that more internal locus of control would be related to lower levels of economic stress and that the relation between stress and locus of control would be mediated by decision making styles, with dependent and avoidant styles being associated with more economic stress than rational and intuitive decision making styles
\end{abstract}

As expected, a more external locus of control was associated with more economic stress as compared to more internal locus of control. There was no association between any decision making styles with locus of control or economic stress and no support for the hypothesis of decision making style as a mediator of this relationship. Results suggest that at times, perceived control over one's economic situation can be predictive of decreased economic stress among a generally low income population. Future research should address whether it may be possible to address economic stress and the detrimental effects it can have through policies that empower individuals to take control over their economic situations, even independent of income. 


\section{Acknowledgements}

I would like to thank Dr. Kathleen Gorman for her ongoing guidance, assistance, and mentoring throughout this long process. I would like to thank Drs. Karen McCurdy and Kathleen Gorman for allowing me access to the subjects of their research.

Additionally, thanks to Drs. Karen McCurdy and Margaret Rogers for agreeing to serve on my committee. Finally, I would like to thank Dr. Diane Martins for serving as the chair at my defense. 


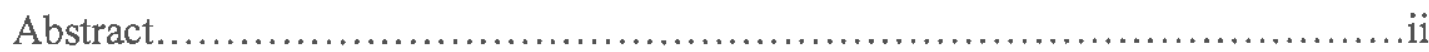

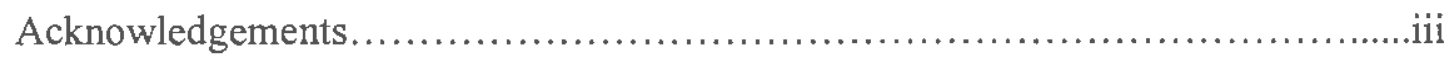

Table of Contents ..............................................................

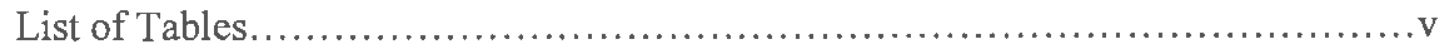

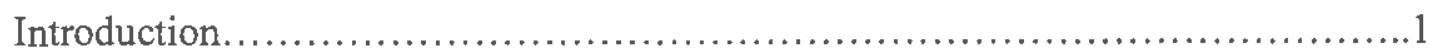

Research Questions.......................................................

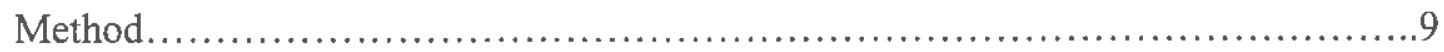

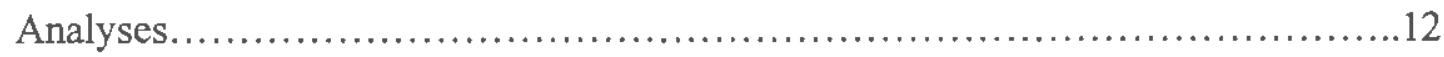

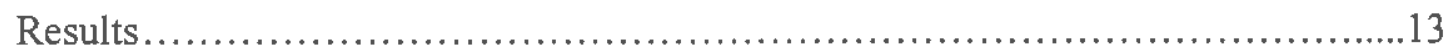

Discussion.......................................................................

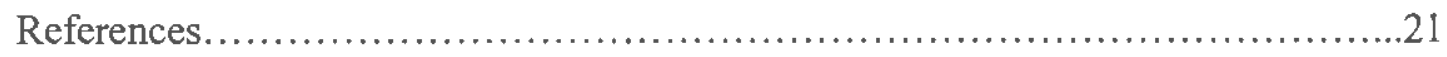

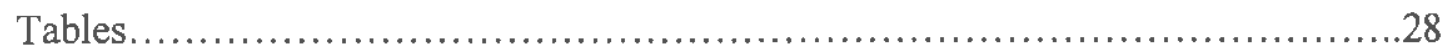

Appendix A: Gurin et al.'s abbreviated version of Rotter's Locus of Control Scale .35 Appendix B: General Decision Making Scale ............................... 37

Appendix C: Economic Stress Items......................................38

Appendix D: Informed Consent Form........................................39

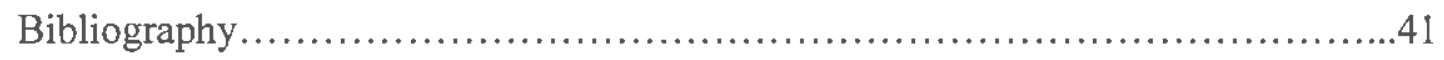




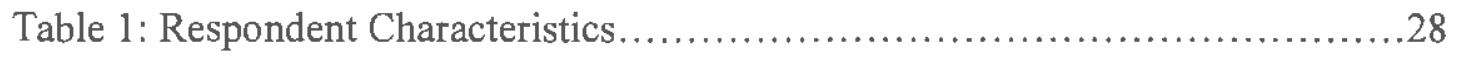

Table 2: Decision-making Styles...........................................

Table 3: Association between locus of Control, Economic Stress,

Decision-Making Styles, and Demographics s.................................. 31

Table 4: Locus of Control, Decision-Making Styles, and Economic Stress...........32

Table 5: Components of Economic Stress Variable.................................. 33

Table 6: Correlations between Decision-Making Styles............................34 


\section{The Low Income Environment}

Low income households experience a wide range of negative outcomes, as poverty typically exists in conjunction with numerous other risk factors. Not only do poor people have less money and ability to make purchases, but Evans (2004) also identifies many psychosocial, physical, and behavioral risks that commonly permeate the environment of poverty, especially for children. For example, low income children have less qualified teachers than high income children (Ingersoll, 1999) and are exposed to a greater incidence of violence (Gallup, 1993). Poor households are often characterized by harsh, punitive parenting, along with parental unresponsiveness toward children (Conger, Conger, Elder, Lorenz, Simons, \& Whitbeck, 1992; Magnusson \& Duncan, 2002, McLoyd, 1998). Not only are poor families at increased risk for negative outcomes, but evidence suggests that cumulative risk may account for even greater risk of poverty, as poverty has been shown to have a strong relationship with exposure to multiple stressors $(\mathrm{R} 2=.19, \mathrm{p}<.001)$ (Evans \& English, 2002).

In addition to psychosocial risk exposure, there is evidence demonstrating a wide range of physical and health risks for low income families. Low income is associated with insufficient nutrition in children (Alaimo, Olson, \& Frongillo, 2001), obesity and overweight among both children (Meyers, Karp, \& Kral, 2006) and adults (Olson, Bove, \& Miller, 2007), as well as depression among adults (Belle \& Doucet, 2003; Wu \& Schimmele, 2006). Low income families regularly experience greater exposure to toxins for adults and children alike, due to the often close proximity of toxic waste dumps to low income neighborhoods (Bullard \& Wright, 1993). Families living in poor areas 
experience greater child problem behavior as reported by parents, including antisocial, delinquent, and aggressive behavior (Reijneveld et al., 2010). Additionally, low income has been associated with decreased mental proficiency in developing children (Zaslow et al., 2008), increased health risks including postponement of seeking healthcare and increased hospitalization (Kushel, Gupta, Gee, \& Haas, 2006), and other poor child behavioral outcomes (Dunifon \& Kowaleski-Jones, 2003).

Low income households typically experience greater food insecurity than higher income households, as well as greater levels of stress and less social support (Seccombe, 2000). These effects of low income have also been shown to result in additional adverse outcomes. Low income parents who are struggling often lack in their ability to provide an optimal environment for raising children. Both food insecurity and lack of social support have been shown to be associated with numerous negative outcomes, such as lack of educational support for children and disengaged parenting (Mayer, 1997; Elder, Eccles, Ardelt, \& Lord, 1995).

\section{Economic Stress}

One way to explain the effects of low income has been to focus on economic stress, defined as the stress that results from financial uncertainty or from a gap between needs and assets (Fox \& Chancey, 1998; Hagquist, 1998; Hraba, Bao, Lorenz, \& Pechacova, 1998). It has more recently been suggested that a focus on the ability of a household to meet basic needs as an indicator of economic stress may not be enough; rather families unable to purchase some "modest wants" may find themselves experiencing economic stress as well (Mistry \& Lowe, 2006; Mistry, Lowe, Benner, \& Chen, 2008). Lower cognitive stimulation, less responsiveness, and less educational achievement are more likely to be present in a family experiencing economic stress 
(McLoyd \& Wilson, 1990). The correlation between linear income and perception of financial resources indicates that economic stress would be more likely among low income families (Mistry et al., 2004). Even among low income families, not all households experience economic stress equally (Whelan \& Maitree, 2007).

Measures of financial well-being, such as economic stress, have been shown to exert influence on the parenting practices that are likely to influence child well-being. The relationship between economic stress and adverse child outcomes, such as problem behavior and social incompetence, is shown to be mediated specifically by maternal processes - maternal depression and low maternal sensitivity (Mistry et al., 2004). For example, research has shown that maternal depression, which has been related to child well-being, is related to income, but this relationship is in part due to perception of financial resources (Mistry, Biesanz, Taylor, Burchinal, \& Cox, 2004). Furthermore, the family economic stress model suggests that perceived financial inadequacy within a household can significantly affect children's behavioral adjustment more than the actual income level of the household; among low income families, as perceived financial inadequacy increases, parents reported greater child problem behavior (Conger \& Elder, 1994).

Given the role of economic stress in contributing toward adverse outcomes, attention should be given to the ability of families to cope with economic stress. It has been suggested that when economic stress is present, financial management strategies may also play an important part in the ability of a family to handle it (Mistry et al, 2008). For example, one study showed that dispositional optimism helped mitigate economic stress and the associated consequences. Specifically, Mexican mothers who were more optimistic about their situations reported feeling less economic stress than those with less 
optimism (Taylor et al., 2012). It is unclear whether economic stress varies according to demographic variables, such as age, sex, and educational level, as studies have tended to control for these rather than investigate differences between them (Conger, Reuter, \& Elder, 1999; Mistry et al., 2008; Whalen \& Maitree, 2007)

\section{Locus of Control}

One factor which may help explain economic stress is locus of control. That is, the degree to which a person perceives control to be in his own hands or the hands of others may influence the degree of economic stress he experiences (Lincoln, Chatters, \& Taylor, 2003). An external locus of control is evident when individuals see events as determined by others; conversely, an individual who sees events as self-determined is said to have an internal locus of control (Mitchell, 1989). An internal locus of control is sometimes referred to in the literature as "perceived control" (Lincoln, Chatters, \& Taylor, 2003). For example, if a person believes she has no control over her economic situation because there are no jobs available, she would be exhibiting an external locus of control. Alternately, if she believes she has control over her situation because she could get a better job if she tried, this would be evident of an internal locus of control. Lincoln et al. (2003) found that financial strain was negatively associated with perceived control. In other words, subjects with increased financial strain had lower perceived control (that is, more external locus of control) than those with less financial strain.

Due to this relationship with economic stress, it is worth further examining locus of control. It is key to understanding the effects of locus of control to note that it is a dynamic construct. Rotter, who was instrumental in the development of the construct of locus of control, emphasized that it is necessary to view locus of control on a continuum, and that to be on one end of the continuum is not necessarily better than to be on the 
other (Rotter, 1975). Positions on the continuum are dynamic, and while locus of control is typically viewed as situational, it can usually predict across a large number of situations for a given person (Rotter, 1975). Over time, however, an individual's locus of control is likely to evolve, rather than to remain the same for the duration of the lifetime (Rotter, 1954). The general tendency is that throughout adult development, people tend to shift toward more internal loci of control, with the likelihood to internalize most around middle age, before gradually beginning to externalize more as the aging process continues (Cain, 1994). While some researchers have attempted to dichotomize individuals into internals and externals, for the most part, locus of control research continues to utilize Rotter's continuum approach (Baiocco, Laghi, \& D'Alessio, 2009; Howell \& Avolio, 1993; Lincoln et al., 2003).

The construct of locus of control was developed out of social learning theory, which asserts in part that individuals will make decisions based on the type of reinforcement they expect as a result of these decisions (Kormanik \& Rocco, 2009; Rotter, 1966). Thus, if they feel they have enough control that their decisions will bring about positive reinforcement, they are likely to exercise such decisions for this reason. However, if they expect that taking these steps would not be likely to yield positive results, due to circumstances' being outside of their control, they would not make these decisions. For example, one study found that subjects who were positively reinforced overestimated their control in a computer-operating task as compared to those who received no reinforcement (Thompson et al., 2007).

\section{Decision Making}

In understanding the relationship between locus of control and economic stress, it is noteworthy that a medium through which locus of control is associated with economic 
stress may be decision making. Decision making has been defined as "the process of choosing between different alternatives while in the midst of pursuing one's goal" (Miller \& Byrnes, 2001). There are five types of decision making styles that are commonly used: avoidant, dependent, intuitive, rational, and spontaneous. The avoidant style involves attempts to avoid making decisions whenever possible; the dependent style is characterized by looking to others for guidance when making decisions; the intuitive style involves attention to detail and likelihood to utilize premonitions and hunches; the rational style is a thorough search for information, evaluated logically through comparison with alternatives; and the spontaneous style is characterized by a sense that a decision must be made as quickly as possible, rushing the decision-making process (Baiocco et al., 2009; Scott \& Bruce, 1995; Spicer \& Sadler-Smith, 2005; Thunholm, $2004,2008,2009)$. The intuitive and the rational decision-making styles are generally categorized as cognitive styles (Anderson, 2000; Thunholm, 2008), and are used by those who employ cognition as a primary problem-solving method. In fact, it has been suggested that the intuitive style is the most effective in business situations, as managers who exhibited this style tended to produce the strongest results in terms of sales and profit numbers (Anderson, 2000). In the area of career decision-making, as indicated by scores on both the Career Maturity Inventory and the Vocational Survey Questionnaire, both intuitive and rational decision making styles have been shown to result in more concrete career plans as compared to dependent decision making styles (Rubinton, 1980).

The relationship between decision making and economic stress has not been specifically examined, although there is some evidence that decision making is related to stress in general, and general stress and economic stress tend to be associated (Fox \& Chancey, 1998; Lincoln et al., 2003). For example, avoidant decision making style was 
found to be associated with high stress among members of the military. In a simulated war scenario, officers who used the avoidant decision-making style (as measured by the General Decision-making Style Inventory (Scott \& Bruce, 1995) demonstrated higher levels of stress (as measured by saliva cortisol release) than those using other decisionmaking styles (Thunholm, 2008). Further, the avoidant and the dependent decision making styles were both related to higher self-reported "perceived stress" (Allwood \& Salo, 2012). Given the association between psychological stress and economic stress (Fox \& Chancey, 1998; Lincoln et al., 2003), it is possible that decision making is related to economic stress as well. One study has found that coping decisions that focus on the problem, rather than on emotions, tend to be associated with lower financial stress and with an internal locus of control (Caplan \& Schooler, 2007). Based on the cognitive theoretical framework behind the rational and intuitive decision making styles, it is expected that these problem-focused coping methods would likely utilize rational and/or intuitive decision-making styles. While the relationship between economic stress and decision making has not been examined in detail, it is viable that decision making mediates the relationship between locus of control and economic stress.

Additional research on the relationship between decision-making and locus of control has suggested that the avoidant and dependent decision-making styles are both associated with an external locus of control. Among adolescents given both the General Decision-making Style Inventory (Scott \& Bruce, 1995) and the Locus of Control Scale (Rotter, 1966), the avoidant and dependent decision making styles (and to a lesser degree the spontaneous decision making style) were both correlated with an external locus of control, while the rational decision making style was associated with an internal locus of control (Baiocco et al., 2009). No significant relationship between the intuitive decision 
making style and locus of control has been found (Baiocco et al., 2009; Thunholm, 2003).

\section{Research Questions}

1. Is there a relationship between locus of control and economic stress? If so, what is this relationship?

Hypothesis: A more internal locus of control is expected to be associated with less economic stress than a more external locus of control.

2. What is the relationship between locus of control and decision making styles, and what is the relationship between decision making styles and economic stress?

Hypothesis: A more internal locus of control will be associated with the rational and intuitive styles while a more external locus of control will be associated with the dependent and avoidant decision making styles.

Hypothesis: The avoidant and dependent decision making styles will be associated with higher economic stress, while rational and the intuitive styles will be associated with higher economic stress.

3. Do decision-making styles mediate the relationship between economic stress and locus of control?

Hypothesis: The relationship between locus of control and economic stress will be mediated by decision making styles. 


\section{Method}

\section{Participants}

Participants were a convenience sample of 68 English-speaking mothers of preschool children (ages 3 to 5) who attend day care centers in Rhode Island. These mothers were a subsample of an NIH-funded study (P.I. Karen McCurdy, IRB \#HU0809047) on the relationship between maternal depression, food insecurity, and child outcomes. The sample consisted only of mothers, because the documented effects of economic stress on children have been shown to be mediated through specifically maternal processes (Mistry et al., 2004). The day care centers serve an ethnically diverse, generally low-income population in Providence, RI. Children enrolled in the day care centers were $30 \%$ Hispanic, $40 \%$ African American, and 30\% white.

\section{Procedure}

Two forms of recruitment were used. First, mothers who already completed the original study were contacted via on-site recruitment in order to request their participation in this study. Additionally, mothers who were recruited for the original study were asked after they completed their interviews if they would like to participate in this study. Mothers who agreed to participate in the original study received $\$ 20$ in cash as an incentive for participation, and participants who agreed to be part of the subsample for this study received an additional \$20. After informed consent was obtained (IRB HU\#180635-4), mothers who agreed to participate in this study took part in an interview lasting approximately 10-15 minutes, during which the three measures: Locus of Control Scale, General Decision-Making Style Inventory, and three questions designed to measure economic stress were verbally administered. Interviews took place at the day care centers unless participants requested an alternate setting. 
Measures

Locus of Control. Locus of control was measured using an abbreviated version of Rotter's (1966) Locus of Control Scale. This 13-item questionnaire has been repeatedly used and validated (Greenberger, Strasser, Cummings, \& Dunham, 1989; Howell \& Avolio,1993), having shown a high reliability $(\alpha=.69)$ and a satisfactory discriminant validity (Gurin, Gurin, \& Morrison, 1979). Each of the 13 items contains two statements, reflecting an internal belief and an external belief. After each of the two statements are read, participants are asked to choose which of the two statements more accurately reflects their own beliefs. For example, one item includes the following two statements: "When I make plans, I am almost certain that I can make them work," (internal); "It is not always wise to plan too far ahead because many things turn out to be a matter of good or bad fortune anyhow." (external). Another asks the participant to choose either - "Becoming a success is a matter of hard work; luck has little or nothing to do with it," (internal) or - "Getting a good job depends mainly on being in the right place at the right time." (external). The scale is counterbalanced, such that the order in which statements representing internal and external views were presented varied. Responses were coded 0 for external and 1 for internal. The 13 item responses are then summed, giving each person a total score ranging from $0-13$, with lower scores indicating a more external locus of control and higher scores reflecting a more internal locus of control. The full measure is included in Appendix A.

Decision Making Styles. Decision making was measured using the General Decision Making Style inventory, developed by Scott and Bruce (1995) and also widely used and validated ( $\alpha$ between 0.68 and 0.94) (Loo, 2000; Spicer \& Sadler-Smith, 2005; Thunholm, 2004; 2008). This scale examines the five decision making styles: rational, 
intuitive, dependent, avoidant, and spontaneous. This measure contains a total of 25 questions, consisting of 5 items for each decision making dimension. Ratings are made using a 5 point Likert scale, with a range of possible answers from "strongly disagree"(1) to "strongly agree"(5). After each statement was read, participants were asked to rate how much they agree with the statement. Examples of statements include: "My decision making requires careful thought," $(\mathrm{R})$ and "I generally make decisions that feel right to me,"(I) as well as "I use the advice of other people in making my important decisions."(D). Items for each of the five scales are summed, giving each participant a score (range 5-25) for each style. Higher scores indicate more frequent use of that style, and respondents may score high (or low) on more than one decision-making style. The General Decision Making Style inventory is located in Appendix B.

Economic Stress. Economic stress was measured using three items used by Mistry et al. (2004), which were shown to be reliable ( $\alpha$ between .67 and .70$)$. Each question is answered on a 5 point Likert scale. The first item is "overall, how satisfied are you with your financial situation?" with possible answers ranging from l=very satisfied to $5=$ very dissatisfied. Next is "how often do you worry about financial matters?" with possible answers ranging from $1=$ almost never to $5=$ almost all of the time. The final item asks "do you know how much money you'll have to live on from one month to the next?" with possible answers ranging from $1=$ almost never to $5=$ almost all of the time. This last item was reverse coded for scale creation, so that higher scores were indicative of more financial stress. This measure is located in Appendix C. 


\section{Analyses}

Economic stress was measured by creating a composite of three individual items. Reliability resulted in an overall Cronbach's alpha of $(\alpha=.58)$. It was found that incorporation of the item called "expectation," which refers to "do you know how much money you will have from one month to another," actually decreased the reliability of the overall model. When this item was removed, reliability increased to $t \alpha=68$. Thus economic stress included 2 items in the composite score. Reliability coefficients for Locus of Control was $\alpha=.60$; reliability for Decision Making Scale was $\alpha=.65$

Next, descriptive statistics were run in order to determine whether there was any association between the socio-demographic variables and the independent and dependent variables. Correlations were assessed for significance between each descriptive variable and each independent and dependent variable.

Intercorrelations were run between the key variables of interest: Locus of control (independent variable), economic stress (dependent variable), and each decision making style.

Given the low reliability of the economic stress variable and lack of statistical association between stress and decision-making styles, post hoc analyses were run correlating decision making styles and each of the individual items of economic stress.

A regression analysis was then run to test for mediators of the relationship between locus of control and "expectation" - the only economic stress question that was significantly correlated with both locus of control and a decision making style - the avoidant. 


\section{Results}

\section{Descriptives}

Participants were ethnically diverse with $43 \%$ of mothers identifying as Hispanic (Table 1). Nearly three quarters of respondents were single, with several of the unmarried mothers living with a partner. Education levels were low, as nearly a quarter of respondents had not completed high school, and a third had graduated from high school but not gone on to any post secondary education. Four percent held bachelor's degrees, and $1.5 \%$ held graduate degrees.

The group was generally low income. Most respondents were working, however, only $29 \%$ were employed for 40 hours or more per week. Five participants had any financial contributions coming from someone outside the household. In general, participants had very low incomes with $28 \%$ reporting month income of $\$ 1001-\$ 1500$, followed by $\$ 501-\$ 1000$ per month $(25 \%)$.

Almost all participants reported receiving some form of government assistance (96\%). The most commonly used assistance program was state-funded health insurance for the children, followed by SNAP, and WIC benefits. Only three respondents reported not receiving benefits from any assistance program (Table 1).

Locus of control scores were varied, as respondents averaged a locus of control result of 6.53 , $(S D=1.73)$ on the scale ranging from 1 to 13 - placing the mean nearly exactly between the external and internal ends of the continuum. Strength of endorsement of decision making styles varied by style, with higher numbers representing greater use of the style. On the scale of 5-25, participants scored highest on the rational decision making style, followed by the intuitive, the dependent, the spontaneous, and the avoidant (Table 
2). On economic stress (the two item composite with a maximum sum score of 10), the mean was $6.9(S D=1.91)$, indicating moderate to high stress across much of the sample.

Associations between the independent and dependent variables and the demographic variables yielded very few significant findings. Correlational analyses indicated a significant association between locus of control and income (more internal was positively related to income) (Table 3 ). Age and education level were not statistically associated with any of the variables of interest. Additionally, race was significantly associated with economic stress, $F(5,66)=3.74, \mathrm{p}=.01$, with participants who were bi- or multi-racial and Asian reporting significantly higher economic stress than American Indian/Alaskan natives. Comparisons on ethnicity showed no significant associations between Hispanics and non-Hispanic whites although Hispanic mothers were slightly more likely $(F(1,66)=3.91 \mathrm{p}=.07)$ than non-Hispanic mothers to use dependent decision-making styles. Participants who were employed were significantly more likely to use the dependent decision-making style than those who did not work $(t(66)=2.160, \mathrm{p}=.03)$. Participants did not differ in any of the measures based on marital status. Because no covariate was significantly associated with both the dependent and the independent variables, none of the covariates were controlled for in the analyses.

\section{Relationship between Locus of Control and Economic Stress}

As expected, locus of control was significantly correlated with economic stress, $r$ $(66)=-.29, \mathrm{p}<.001)($ Table 4$)$. Results showed that a more internal locus of control was related to lower economic stress.

\section{Relationship between Locus of Control and Decision Making Styles}

It was hypothesized that a more internal locus of control would be associated with the rational and intuitive decision making styles, while a more external locus of control 
would be associated with the dependent and avoidant styles. In contrast to hypotheses, results showed that locus of control was not significantly correlated with any decision making style at the $p<.05$ level (Table 4). Two decision making styles, the rational, $r(66)$ $=.21$, and the avoidant, $r(66)=.23$, were related to locus of control in the expected directions, at the non-significant $p<.10$ level.

\section{Relationship between Decision Making Styles and Economic Stress}

The hypothesis was that the avoidant and dependent decision making styles would be associated with more economic stress than the rational or intuitive styles. Economic stress, however, was not shown to be significantly correlated with any decision making style (Table 4). Because no decision making styles were significantly correlated with economic stress, it was concluded that, contrary to the hypothesis, there was no support for decision making styles' mediating the relationship between locus of control and economic stress.

\section{Post hoc analyses}

Because our initial composite variable of economic stress showed lower than expected internal consistency, the three individual items (worry, expectation, and satisfaction) were analyzed separately in relation to decision-making styles. Results showed that the avoidant and the spontaneous decision making styles were significantly related to expectation and worry, respectively (Table 5). That is, higher use of the avoidant decision making style was associated with reported great uncertainty about how much money one would have from one month to the next and higher utilization of the spontaneous style was associated with greater worry about financial matters.

Additionally, because there was a significant relationship between locus of control and "expectation," the avoidant decision making style was tested as a possible 
mediator in this relationship. A regression analysis was run to test whether the avoidant decision making style mediated the relationship between locus of control and expectation of financial stability; results were non-significant, indicating that there was no evidence of a mediating relationship, $t(66)=1.425, \mathrm{p}=.16)$. 


\section{Discussion}

The purpose of this study was to investigate the role of locus of control and decision making styles in contributing to variations in economic stress among a lowincome population. More specifically, the intent was to determine whether locus of control was associated with economic stress and whether certain decision making styles acted as mediators between locus of control and economic stress. It was expected that locus of control would be significantly related to economic stress, and that this relationship would be mediated by decision making styles. The results provided limited support for the hypotheses. First, as expected, participants who demonstrated a more external locus of control score were more likely to experience economic stress. Neither locus of control nor economic stress was, however, related to decision making styles, and given that point, decision making styles - contrary to the hypothesis - did not mediate the relationship between locus of control and economic stress. The implications of each of these findings will be further discussed.

Interestingly, in the post-hoc analyses we saw that those with more external loci of control were only marginally more likely to report worrying about their financial situations, be unsatisfied with their economic situations, or unlikely to know how much money to expect they would have from one month to the next than those with internal loci of control. Taken together, the composite measure more strongly captured a level of stress that significantly predicted to locus of control than did any individual component of it. This is indicative of the multidimensional nature of economic stress; when multiple components are combined into a composite, economic stress is more fully captured. 
These findings suggest that among a low income population, a feeling that one has control over his or her economic situation is likely to ease the burden of financial stress, and a lack of perceived control is likely to exacerbate it. Economic stress is often the result of a culmination of factors, and when taken together, can be somewhat less stressful if there is a sense of control over one's financial situation (Lincoln, Chatters, \& Taylor, 2003). It should be noted that this was in general a consistently low income sample, so this is not a statement of lack of association between economic stress and income.

In contrast to hypotheses, feelings of perceived control were not related to decision making styles as expected. There were no relationships between locus of control and decision making styles. One explanation for this may be that the relationship between locus of control and economic stress may be largely a product of perception. This would be in line with the finding of Lincoln et al. (2003) who reported that financial strain has a negative association with perceived control among a group of African American and white adults. Interestingly, the findings reported here extend to a more targeted sample of low income mothers of preschool children. This furthers the research on locus of control and economic stress, as examination of this relationship thus far has been fairly limited.

Finally, it is interesting to note that economic stress was not related to any of the demographic variables with the exception of a marginally significant relationship with mother's education level $(\mathrm{p}<.06)$. This reaffirms that even among low- income samples, not all families will experience economic stress equally.

There were several limitations to this study. The fact that we were unable to establish a significant relationship between income and economic stress was inconsistent with previous research. In this study, approximately half of the sample did not provide an 
exact income amount but rather indicated that their income fell within a predetermined range. As such, the income variable is somewhat unreliable and represents broad categories rather than actual income. This may have limited the ability to detect an effect. Additionally, the sample did not vary widely on income. Nearly $80 \%$ of respondents had incomes below $\$ 2000$ monthly (Table 1). This lack of variation further added to the difficulty in establishing a relationship of income and economic stress.

Another limitation may have been sample size. In some cases, results approached significance $(p<.10)$, but did not reach significance at the .05 level. For example, two decision making styles, the rational and the avoidant, approached significance in their relationships with locus of control. It is possible that a larger sample size would have taken this directional effect to a level of significance, thereby in part providing support for the hypotheses. Future research should use larger sample sizes when examining these constructs, as this is reason to suspect effects may exist which were simply too small to be detected with this modest sample size.

Additionally, the rational and intuitive decision making styles, as well as the avoidance and spontaneous decision making styles were significantly intercorrelated with one another (Table 6). This suggests that the five decision making styles may not be entirely independent and that possibly combining styles may provide a better assessment of an individual's overall decision-making style. Furthermore, when examining decision making style preferences, it is interesting to note that among this sample of low-income mothers, rational decision making style was the most frequently used among all participants. Further research will need to establish whether decision-making styles are similar across different types of populations. Research on decision making styles has thus far targeted specific groups - such as members of the military. It is possible that the 
measure for decision making styles may not have carried the level of neutrality that was intended.

The findings of this study - particularly the relationship between locus of control and economic stress - carry important implications. The benefit of perceived control, as exemplified through this relationship, emphasizes the importance of access to the tools which do empower people to take a degree of control over their economic situations, such as education. As was noted earlier, it is not only low income that carries with it problematic side effects; it can be economic stress as well (McLoyd \& Wilson, 1990). Therefore, while improving access to education alone may not be able to increase the number of available jobs offering a livable wage, the findings here suggest that any steps taken to improve even one's feelings about his or her prospects for economic improvement may potentially play a role in alleviating economic stress and the problems that often accompany it. It is important that education be made affordable and accessible to all - particularly those most susceptible to low income and economic stress - in order to increase the amount of control that all of us have over our financial situations. Further research should examine the extent to which perceived control may help alleviate economic stress. 


\section{References}

Alaimo, K., Olson, C. M., \& Frongillo, E. A. (1999). Importance of cognitive testing for survey items: An example from food security questionnaires. Journal of Nutrition Education, 31 (5), 269-275.

Allwood, C. M. \& Salo, I. (2012). Decision-making styles and stress. International Journal of Stress Management, 19 (1), 34-47.

Andersen, J. A. (2000). Intuition in managers; Are intuitive managers more effective? Journal of Managerial Psychology, 15 (1), 46-67.

Baiocco, R., Laghi, F., \& D'Alessio, M. (2009). Decision-making style among adolescents: Relationship with sensation seeking and locus of control. Journal of Adolescence, 32, 963-976.

Belle, D., \& Doucet, J. (2003). Poverty, inequality, and discrimination as sources of depression among U. S. women. Psychology of Women Quarterly, 27, 101-113.

Bullard, R. D., \& Wright, B. (1993). Environmental justice for all: Current perspectives on health and research needs. Toxicology and Industrial Health, 9, 821-841.

Cain, R. A. (1994). Perception of power/control among African Americans: A developmental approach. Western Journal of Black Studies, 18 (3), 164-174.

Caplan, L. J., \& Schooler, C. (2007). Socioeconomic status and financial coping strategies: The mediating role of perceived control. Social Psychology Quarterly, $70(1), 43-58$.

Conger, R. D., Conger, K. J., Elder, G. H., Lorenz, F. O., Simons, R. L., \& Whitbeck, L. B. (1992). A family process model of economic hardship and adjustment of early adolescent boys. Child Development, 63 (3), 526-541. 
Conger, R. D., Rueter, M. A. \& Elder, G. H. (1999). Couple resilience to economic pressure. Journal of Personality and Social Psychology, 76 (1), 54-71.

Deardorff, J., Gonzales, N. A., \& Sandler, I. N. (2003). Journal of Abnormal Child Psychology, 31 (2), 205-217.

Dunifon, R., \& Kowaleski-Jones, L. (2003). The influences of participation in the National School Lunch Program and food insecurity on child well-being. The Social Science Review, 77 (1), 72-92.

Elder, G. H., Eccles, J. S., Ardelt, M., \& Lord, S. (1995). Inner-city parents under economic pressure: Perspectives on the strategies of parenting. Journal of Marriage and the Family, 57 (1), 771-784.

Evans, G. W. (2004) The environment of childhood poverty. American Psychologist, 59 (2), 77-92.

Evans, G. W., \& English, K. (2002). The environment of poverty: Multiple stressor exposure, psychophysiological stress, and socioemotional adjustment. Child Development, 73 (4), 1238-1248.

Fairbrother, G., Kenney, G., Hanson, K., \& Dubay, L. (2005). How do stressful family environments relate to reported access and use of health care by low-income children? Medical Care Research and Review, 62, 205-230.

Fox, G. L. \& Chancey, D. (1998). Sources of economic distress: Individual and family outcomes. Journal of Family Issues, 19, 725-749.

Gallup, G. (1993). America's youth in the 1990's. Princeton, NJ: Gallup Institute.

Gennetian, L. A., \& Miller, C. (2002). Children and welfare reform: A view from an experimental welfare program in Minnesota. Child Development, 73 (2), 601-620.

Greenberger, D. B., Strasser, S., Cummings, L. L., \& Dunham, R. B. (1989). The impact 
of personal control on performance and satisfaction. Organizational Behavior and Human Decision Processes, 43, 29-51.

Gurn, P., Gurin, G., \& Morrison, B. M. (1978). Personal and ideological aspects of internal and external control. Social Psychology, 41, 275-296.

Hagquist, C. E. I. (1998). Economic stress and perceived health among adolescents in Sweden. Journal of Adolescent Health, 22, 250-257.

Howell, J. M., \& Avolio, B. J. (1993). Transformational leadership, transactional leadership, locus of control, and support for innovation: Key predictors of consolidated-business-unit performance. Journal of Applied Psychology, 78, 6, $891-902$.

Hraba, J., Bao, W., Lorenz, F. O., \& Pechacova, Z. (1998). Perceived risk of crime in the Czech Republic. Journal of Research in Crime and Delinquency, 35 (2), 225-242. Ingersoll, R. (1999). The problem of under qualified teachers in American secondary schools, Educational Researcher, 28, 26-37.

Kormanik, M. B., \& Rocco, T. S. (2009). Internal versus external control of reinforcement: A review of the locus of control construct. Human Resource Development Review, 8 (4), 463-483.

Kushel, M. B., Gupta, R., Gee, L., \& Haas, J. S. (2006). Housing instability and food insecurity as barriers to health care among low-income Americans. Journal of General Internal Medicine, 21, 71-77.

Lincoln, K. D., Chatters, L. M., \& Taylor, R. J. (2003). Psychological distress among black and white Americans: Differential effects of social support, negative interaction, and personal control. Journal of Health and Social Behavior, 44 (3), $390-407$. 
Magnusson, K. A., \& Duncan, G. J. (2002). Parents in poverty. In M. H. Bornstein (Ed.), Handbook of parenting ( $2^{\text {nd }}$ ed., pp. 95-121). Mahwah, NJ: Erlbaum.

Mayer, S. (1997). What money can't buy. Cambridge, MA: Harvard University Press.

McGill-Franzen, A., Lanford, C., \& Adams, E. (2002). Learning to be literate: A comparison of five urban early childhood programs. Journal of Educational Psychology, 94 (3), 445-464.

McLoyd, V. C. (1998). Socioeconomic disadvantage and child development. American Psychologist, 53, 185-204.

McLoyd, V. C., \& Wilson, L. (1990). Maternal behavior, social support, and economic conditions as predictors of distress in children. New Directions for Child Development, 46, 49-69.

Meyers, A. F., Karp, R. J., \& Kral, J. G. (2006). Poverty, food insecurity, and obesity in children. Pediatrics, 118, 2265a-2266.

Miller, D. C., \& Byrnes, J. P. (2001). Adolescents' decision-making in social situations: A self-regulation perspective. Applied Developmental Psychology, 22, 237-256.

Mistry, R. S., Biesanz, J., Taylor, L. C., Burchinal, M., and Cox, M. J. (2004). Family income and its relation to preschool children's adjustment for families in the NICHD study of early child care. Developmental Psychology, 40, (5), 727-745.

Mistry, R. S., Lowe, E. D., Benner, A. D., \& Chien, N. (2008). Expanding the family economic stress model: Insights from a mixed-models approach. Journal of Marriage and Family, 70, 196-209.

Mistry, R. S., Benner, A. D., Biesanz, J., Clark, S., \& Howes, C. (in press). Family and social risk, and parental investments during the early childhood years as predictors of low-income children's school readiness outcomes. Early Childhood 
Research Quarterly.

Mitchell, C. E. (1989). Internal locus of control for expectation, perception and management of answered prayer. Journal of Psychology and Theology, 17 (1), 2126.

Nnakwe, N. E. (2008). Dietary patterns and prevalence of food insecurity among lowincome families participating in community food assistance programs in a midwest town. Family and Consumer Sciences Research Journal, 36 (3), 229242.

Olson, C. M., Bove, C. F., \& Miller, E. O. (2007). Growing up poor: Long-term implications for eating patterns and body weight. Appetite, 49, 198-207.

Reijneveld, S. A., Veenstra, R., de Winter, A. F., Verhlst, F. C., Ormel, J., \& de Meer, G. (2010). Area deprivation affects behavioral problems of young adolescents in mixed urban and rural areas: The TRAILS study. Journal of Adolescent Health, 46, 189-196.

Rotter, J. B. (1954). Social learning and clinical psychology. Englewood Cliffs, NJ: Prentice-Hall.

Rotter, J. B. (1966). Generalized expectancies for internal versus external control of reinforcement. Psychological Monographs: General and Applied, 1.

Rotter, J. B. (1975). Some problems and misconceptions related to the construct of internal versus external control of reinforcement. Journal of Counseling and Clinical Psychology, 43 (1), 55-67.

Rubinton, N. (1980), Instruction in career decision making and decision-making styles. Journal of Counseling Psychology, 27 (6), 581-588.

Scott, S. G., \& Bruce, R. A. (1995). Decision-making style: The development and 
assessment of a new measure. Educational and Psychological Measurement, 55 (5), 818-831.

Seccombe, K (2000). Families in poverty in the 1990s: Trends, causes, consequences, and lessons learned. Journal of Marriage and the Family, 62 (4), 1094-1113.

Shek, D. T. L. (2005). Economic stress, emotional quality of life, and problem behavior in Chinese adolescents with and without economic disadvantage. Social Indicators Research, 71 (1/3), 363-383.

Spicer, D. P., \& Sadler-Smith, E. (2005). An examination of the general decision making style in two U. K. samples. Journal of Mangerial Psychology, 20 (1/2), 137-149.

Taylor, Z. E., Widaman, K. F., Robins, R. W., Jochem, R., Early, D. R., \& Conger, R. D. (2012). Dispositional optimism: A psychological resource for Mexican-origin mothers experiencing economic stress. Journal of Family Psychology, 26 (1), 133-139.

Thompson, S. C., Nierman, A., Schlehofer, M. M., Carter, E., Bovin, M. J., Wurzman, L., Tauber, P., Trifskin, S., Marks, P., Sumner, J., Jackson, A., \& Vonasch, A. (2007). How do we judge personal control? Unconfounding contingency and reinforcement in control judgments. Basic and Applied Social Psychology, 29 (1), $75-84$.

Thunholm, P. (2004). Decision-making: Habit, style, or both? Personality and Individual Differences, $36(4), 931-944$.

Thunholm, P. (2008). Decision-making styles and physiological correlates of negative stress: Is there a relation? Scandinavian Journal of Psychology, 49, 213-219.

Thunholm, P. (2009). Military leaders and followers- do they have different decision styles? Scandinavian Journal of Psychology, 50, 317-324. 
Whelan, C. T., \& Maitre, B. (2007). Income, deprivation, and economic stress in the enlarged European Union. Social Indicators Research, 83, 309-329.

Wu, Z., \& Schimmele, C. M. (2006). Food insufficiency and depression. Sociological Perspectives, 48 (4), 481-504.

Zaslow, M., Bronte-Tinkew, J., Capps, R., Horowitz, A., Moore, K. A., \& Weinstein, D. (2009). Food security during infancy: Implications for attachment and mental proficiency in toddlerhood. Maternal and Child Health Journal, 13, 66-80. 
Table 1

Respondent Characteristics

\begin{tabular}{lcc}
\hline Variable & $\mathrm{N}$ & $\begin{array}{c}\text { \% of Survey } \\
\text { Population }\end{array}$ \\
\hline Entire sample & 68 & \\
Race & &
\end{tabular}

Black

20

$29.4 \%$

White

10

$14.7 \%$

Other $^{1}$

13

$19.1 \%$

No answer*

25

$36.8 \%$

Hispanic Status

Hispanic

29

$42.6 \%$

Non-Hispanic

39

$57.4 \%$

Language Preferred

English

60

$88.2 \%$

Spanish

6

$8.8 \%$

Other Reply

2

$3.0 \%$

Educational Level

$11^{\text {th }}$ grade or below

$22.0 \%$

High School Diploma/GED

24

$35.5 \%$

Some post secondary ${ }^{2}$

23

$33.9 \%$

Bachelor's degree or beyond

4

$5.9 \%$

No answer

2

$2.9 \%$

\footnotetext{
${ }^{1}$ Include bi/multiracial (3), American Indian or Alaskan native (3), Asian (2) and unspecified (5)

${ }^{2}$ Includes some college (14) vocational (5) and associates degree (4)
} 
Weekly Hours Worked

Less than 20 hours

4

$5.9 \%$

20-29 hours

13

$19.1 \%$

30-39 hours

18

$26.5 \%$

40 hours or more

20

$29.4 \%$

Do not work

13

$19.1 \%$

Income

Less than $\$ 1000$

22

$32.4 \%$

$\$ 1001-\$ 2000$

32

$47.0 \%$

$\$ 2001-\$ 3000$

7

$10.3 \%$

Over $\$ 3000$

7

$10.3 \%$

Assistance Programs Used

Rite Care

52

$76.5 \%$

SNAP (Food Stamp)

44

$64.7 \%$

WIC

41

$60.3 \%$

Subsidized Child Care

41

$60.3 \%$

Heating Assistance

26

$38.2 \%$

RI Works/Welfare/FIP

21

$30.9 \%$

Head Start

16

$23.5 \%$

SSI

8

$11.8 \%$

Other

4

$5.9 \%$

\footnotetext{
*No answer was given in cases where respondents claimed Hispanic only and added no specifications.
} 
Table 2

Decision-making Styles

\begin{tabular}{lcc}
\hline \multicolumn{1}{c}{ Decision-making Style } & Mean & $\begin{array}{c}\text { Standard } \\
\text { Deviation }\end{array}$ \\
\hline Rational & 15.59 & 2.54 \\
Intuitive & 14.65 & 2.82 \\
Dependent & 11.84 & 3.36 \\
Spontaneous & 9.86 & 4.21 \\
Avoidant & 8.65 & 3.77 \\
\hline
\end{tabular}


Table 3

Association between Locus of Control, Economic Stress, Decision-making styles and

Demographics

\begin{tabular}{lccc}
\hline Measure & Income & Education & Age \\
\hline Locus of Control & $0.26^{*}$ & -0.05 & -0.14 \\
Economic stress & -0.09 & 0.23 & -0.10 \\
Rational decision-making style & -0.01 & 0.03 & 0.10 \\
Intuitive decision-making style & -0.05 & -0.03 & -0.01 \\
Avoidant decision-making style & -0.11 & -0.14 & -0.00 \\
Dependent decision-making style & 0.12 & -0.05 & 0.20 \\
Spontaneous decision-making style & 0.07 & -0.22 & 0.02 \\
\hline
\end{tabular}

Note. Significant correlation, $\dagger p<.10,{ }^{*} p<.05,{ }^{* *} p<.01$

Note. Income was categorized as $<\$ 1000$, between $\$ 1000$ and $\$ 2000$, between $\$ 2000$ and $\$ 3000$, between $\$ 3001$ and $\$ 4000$, and over $\$ 4,000$ per month. Education was categorized as less than $8^{\text {th }}$ grade, $9^{\text {th }}$ through $11^{\text {th }}$ grade, high school diploma, some postsecondary, bachelor's degree, master's degree and beyond.

Note. Income and Education use Spearman rhos. Age uses Pearson product-moment correlation coefficients. 
Table 4

Locus of Control, Decision Making Styles, and Economic Stress

Spearman Correlation Coefficient

Measure

Locus of Control

Economic Stress

\begin{tabular}{lcc}
\hline Rational decision-making style & $0.21 \dagger$ & -0.07 \\
Intuitive decision-making style & 0.16 & -0.05 \\
Dependent decision-making style & 0.00 & 0.07 \\
Avoidant decision-making style & $-0.23 \dagger$ & 0.10 \\
Spontaneous decision-making style & -0.15 & 0.17 \\
Economic stress & $-0.29^{*}$ & -- \\
Locus of Control & -- & $-0.29^{* *}$ \\
\hline
\end{tabular}

Note. Significant correlation, $\uparrow p<.10,{ }^{*} p<.05,{ }^{* *} p<.01$ 
Table 5

Components of Economic Stress Variable

Spearman Correlation Coefficient

Measure

Satisfaction Expectation Worry

\begin{tabular}{llll}
\hline Rational decision-making style & -0.09 & -0.13 & -0.02 \\
Intuitive decision-making style & -0.05 & -0.15 & -0.03 \\
Avoidant decision-making style & 0.03 & $0.23^{*}$ & 0.15 \\
Dependent decision-making style & -0.14 & 0.05 & 0.03 \\
Spontaneous decision-making style & 0.07 & 0.04 & $0.23^{*}$ \\
Locus of Control & -0.09 & -0.13 & -0.02 \\
\hline
\end{tabular}

Note. Significant correlation, $\nmid p<.10,{ }^{*} p<.05,{ }^{* *} p<.01$ 
Table 6

Correlations between Decision Making Styles

\begin{tabular}{lccccc}
\hline \multicolumn{1}{c}{ Measure } & \multicolumn{5}{c}{ Pearson Correlation Coefficient } \\
\cline { 2 - 6 } & Rational & Intuitive & Dependent & Avoidant & $\begin{array}{c}\text { Spontaneou } \\
\text { s }\end{array}$ \\
\hline Rational & -- & $0.52^{* *}$ & 0.14 & $-0.24^{*}$ & -0.11 \\
Intuitive & $0.52^{* *}$ & -- & 0.04 & 0.02 & 0.16 \\
Dependent & 0.14 & 0.04 & -- & $0.23 \dagger$ & 0.08 \\
Avoidant & $-0.24^{*}$ & 0.02 & $0.23 \dagger$ & -- & $0.53^{* *}$ \\
Spontaneous & -0.11 & 0.16 & 0.08 & $0.53^{* *}$ & -- \\
\hline
\end{tabular}

Note. Significant correlation, $\uparrow p<.10,{ }^{*} p<.05,{ }^{* *} p<.01$ 
Appendix A: Gurin et al.'s abbreviated version of Rotter's Locus of Control Scale

1) A. Becoming a success is a matter of hard work; luck has little or nothing to do with it.

B. Getting a good job depends mainly on being in the right place at the right time

2) A. Who gets to be the boss often depends on who was lucky enough to be in the right place first.

B. Who gets to be the boss depends on who has the skill and ability; luck has little or nothing to do with it.

3) A. I have often found that what is going to happen will happen.

B. Trusting to fate has never turned out as well for me as making a decision to take a definite course of action.

4) A. When I make plans, I am almost certain that I can make them work.

B. It is not always wise to plan too far ahead because many things turn out to be a matter of good or bad fortune anyhow.

5) A. In my case, getting what I want has little or nothing to do with luck.

B. Many times we might just as well decide what to do by flipping a coin.

6) A. Many times I feel that I have little influence over the things that happen to me. B. It is impossible for me to believe that chance or luck play an important role in my life.

7) A. What happens to me is my own doing.

B. Sometimes I feel that I don't have enough control over the direction my life is taking.

8) A. No matter how hard you try, some people just don't like you.

B. People who can't get others to like them don't understand how to get along with others.

9) A. It is hard to know whether or not a person really likes you.

B. How many friends you have depends upon how nice a person you are.

10) A. People are lonely because they don't try to be friendly.

B. There's not much use in trying too hard to please people; if they like you they like you.

11) A. In the long run, people get the respect they deserve in this world.

B. Unfortunately, an individual's worth often passes unrecognized no matter how hard he tries. 
12) A. One of the major reasons why we have wars is because people don't take enough interest in politics.

B. There will always be wars, no matter how hard people try to prevent them.

13) A. Leadership positions tend to go to capable people who deserve being chosen. B. It's hard to know why some people get leadership positions and others don't. Ability doesn't seem to be important factor.

Score 1 point for each of the following:

- $1 \mathrm{a}$

- $2 b$

- $3 \mathrm{~b}$

- $4 \mathrm{a}$

- $5 \mathrm{a}$

- $6 \mathrm{~b}$

- $7 \mathrm{a}$

- $8 b$

- $9 b$

- $10 \mathrm{a}$

- 11a

- $12 \mathrm{a}$

- $13 \mathrm{~b}$ 
1. I double-check my information sources to be sure I have the right facts before making a decision (Rational)

2. When making a decision. I rely upon my instincts (Intuitive)

3. I often need the assistance of other people when making important decisions (Dependent)

4. I avoid making important decisions until the pressure is on (Avoidant)

5. I generally make snap decisions (Spontaneous)

6. I make decisions in a logical and systematic way (Rational)

7. When I make decisions. I tend to rely on my intuition (Intuitive)

8. I rarely make important decisions without consulting other people (Dependent)

9. I postpone decision making whenever possible (Avoidant)

10. I often make decisions on the spur of the moment (Spontaneous)

11. My decision making requires careful thought (Rational)

12. I generally make decisions that feel right to me (Intuitive)

13. If I have the support of others. it is easier for me to make important decisions (Dependent)

14. I often procrastinate when it comes to making important decisions (Avoidant)

15. I make quick decisions (Spontaneous)

16. When making a decision. I consider various options in terms of a specific goal (Rational)

17. When I make a decision. it is more important for me to feel the decision is right than to have a rational reason for it (Intuitive)

18. I use the advice of other people in making my important decisions (Dependent)

19. I generally make important decisions at the last minute (Avoidant)

20. I often make impulsive decisions (Spontaneous)

21. I explore all of my options before making a decision (Rational)

22. When I make a decision. I trust my inner feelings and reactions (Intuitive)

23. I like to have someone to steer me in the right direction when I am faced with important decisions (Dependent)

24. I put off making many decisions because thinking about them makes me uneasy (Avoidant) 
Appendix C: Economic Stress items

1. Overall, how satisfied are you with your financial situation?

1 (very dissatisfied) 2 (dissatisfied) $\quad 3$ (unsure) 4 (satisfied) $\quad 5$ (very satisfied)

2. How often do you worry about financial matters?

1 (almost never) $\quad 2$ (rarely) 3 (sometimes) 4 (often) 5 (almost all of the time)

3. Do you know how much money you'll have to live on from one month to the next?

1 (almost never) $\quad 2$ (rarely) 3 (sometimes) 4 (often) 5 (almost all of the time) 
Appendix D: Informed Consent Form

University of Rhode Island

Department of Psychology

Locus of Control and Decision Making Styles as Predictors of Economic Stress

\section{CONSENT FORM FOR RESEARCH \\ Locus of Control and Decision Making Styles as Predictors of Economic Stress}

You have been invited to take part in a research project described below. The researcher will explain the project to you in detail. You should feel free to ask questions. If you have more questions later, Stephen Favasuli, the person mainly responsible for this study, 401-952-3061, will discuss them with you. Once you understand the study and all that it requires, you will be asked to sign this form if you are wiling to participate.

Description of the project:

The purpose of this study is to understand better how the ways people make decisions and the reasons they believe things happen may be related to the amount of financial stress in their households. This study is being done in cooperation with your child's day care center. The information we get from this study will be used to better understand these relationships and to guide future research that will try to help reduce economic stress.

What will be done:

If you decide to take part in this study here is what will happen: You will be asked to complete a verbal questionnaire that should take about 15-20 minutes. You can complete this questionnaire at your child's day care center or at some other location that is convenient for you. You will receive $\$ 20$ in cash for completing the questionnaire.

\section{Risks or discomfort:}

Risks of participating in this study are extremely minimal for you. You may experience psychological discomfort from discussing stressful experiences, but there are no other known risks of participation.

Benefits of this study:

Although there will be no direct benefit to you for taking part in this study, the information you provide may help guide future efforts aimed at reducing economic stress among families.

\section{Confidentiality:}

Your part in this study is confidential. None of the information will identify you by name. All information collected from you will be identified with numerical codes, and your names will not be attached to this information. All paper records and questionnaires will be kept in a locked file cabinet where only the researcher will have access to it. Your information will not be shared with anyone at your child's day care center. 
Decision to quit at any time:

The decision to take part in this study is up to you. You do not have to participate. If you decide to take part in the study, you may quit at any time. Whatever you decide will in no way affect any services you receive, including those your child receives at the day care center. If you wish to quit, simply inform Stephen Favasuli at 401-952-3061 of your decision.

Rights and Complaints:

If you are not satisfied with the way this study is performed, you may discuss your complaints with Stephen Favasuli at 401-952-3061, anonymously, if you choose. In addition, if you have questions about your rights as a research participant, you may contact the office of the Vice President for Research, 70 Lower College Road, Suite 2, University of Rhode Island, Kingston, Rhode Island, telephone: (401) 874-4328.

\section{Signatures}

You have read the Consent Form. Your questions have been answered. Your signature on this form means that you understand the information and you agree to participate in this study. Please keep one copy of this form for your records.

Signature of Participant

Typed/printed Name
Signature of Researcher

Typed/printed name

Date

Date

Please sign both consent forms, keeping one for yourself 


\section{Bibliography}

Alaimo, K., Olson, C. M., \& Frongillo, E. A. (1999). Importance of cognitive testing for survey items: An example from food security questionnaires. Journal of Nutrition Education, 31 (5), 269-275.

Allwood, C. M. \& Salo, I. (2012). Decision-making styles and stress. International Journal of Stress Management, 19 (1), 34-47.

Andersen, J. A. (2000). Intuition in managers; Are intuitive managers more effective? Journal of Managerial Psychology, 15 (1), 46-67.

Baiocco, R., Laghi, F., \& D’Alessio, M. (2009). Decision-making style among adolescents: Relationship with sensation seeking and locus of control. Journal of Adolescence, 32, 963-976.

Belle, D., \& Doucet, J. (2003). Poverty, inequality, and discrimination as sources of depression among U. S. women. Psychology of Women Quarterly, 27, 101-113.

Bullard, R. D., \& Wright, B. (1993). Environmental justice for all: Current perspectives on health and research needs. Toxicology and Industrial Health, 9, 821-841.

Cain, R. A. (1994). Perception of power/control among African Americans: A developmental approach. Western Journal of Black Studies, 18 (3), 164-174.

Caplan, L. J., \& Schooler, C. (2007). Socioeconomic status and financial coping strategies: The mediating role of perceived control. Social Psychology Quarterly, $70(1), 43-58$.

Conger, R. D., Conger, K. J., Elder, G. H., Lorenz, F. O., Simons, R. L., \& Whitbeck, L. B. (1992). A family process model of economic hardship and adjustment of early adolescent boys. Child Development, 63 (3), 526-541.

Conger, R. D., Rueter, M. A. \& Elder, G. H. (1999). Couple resilience to economic 
pressure. Journal of Personality and Social Psychology, 76 (1), 54-71.

Deardorff, J., Gonzales, N. A., \& Sandler, I. N. (2003). Journal of Abnormal Child Psychology, 31 (2), 205-217.

Dunifon, R., \& Kowaleski-Jones, L. (2003). The influences of participation in the National School Lunch Program and food insecurity on child well-being. The Social Science Review, 77 (1), 72-92.

Elder, G. H., Eccles, J. S., Ardelt, M., \& Lord, S. (1995). Inner-city parents under economic pressure: Perspectives on the strategies of parenting. Journal of Marriage and the Family, 57 (1), 771-784.

Evans, G. W. (2004) The environment of childhood poverty. American Psychologist, 59 (2), 77-92.

Evans, G. W., \& English, K. (2002). The environment of poverty: Multiple stressor exposure, psychophysiological stress, and socioemotional adjustment. Child Development, 73 (4), 1238-1248.

Fairbrother, G., Kenney, G., Hanson, K., \& Dubay, L. (2005). How do stressful family environments relate to reported access and use of health care by low-income children? Medical Care Research and Review, 62, 205-230.

Fox, G. L. \& Chancey, D. (1998). Sources of economic distress: Individual and family outcomes. Journal of Family Issues, 19, 725-749.

Gallup, G. (1993). America's youth in the 1990's. Princeton, NJ: Gallup Institute.

Gennetian, L. A., \& Miller, C. (2002). Children and welfare reform: A view from an experimental welfare program in Minnesota. Child Development, 73 (2), 601-620.

Greenberger, D. B., Strasser, S., Cummings, L. L., \& Dunham, R. B. (1989). The impact of personal control on performance and satisfaction. Organizational Behavior and 
Human Decision Processes, 43, 29-51.

Gurn, P., Gurin, G., \& Morrison, B. M. (1978). Personal and ideological aspects of internal and external control. Social Psychology, 41, 275-296.

Hagquist, C. E. I. (1998), Economic stress and perceived health among adolescents in Sweden. Journal of Adolescent Health, 22, 250-257.

Howell, J. M., \& Avolio, B. J. (1993). Transformational leadership, transactional leadership, locus of control, and support for innovation: Key predictors of consolidated-business-unit performance. Journal of Applied Psychology, 78, 6, 891-902.

Hraba, J., Bao, W., Lorenz, F. O., \& Pechacova, Z. (1998). Perceived risk of crime in the Czech Republic. Journal of Research in Crime and Delinquency, 35 (2), 225-242.

Ingersoll, R. (1999). The problem of under qualified teachers in American secondary schools, Educational Researcher, 28, 26-37.

Kormanik, M. B., \& Rocco, T. S. (2009). Internal versus external control of reinforcement: A review of the locus of control construct. Human Resource Development Review, 8(4), 463-483.

Kushel, M. B., Gupta, R., Gee, L., \& Haas, J. S. (2006). Housing instability and food insecurity as barriers to health care among low-income Americans. Journal of General Internal Medicine, 21, 71-77.

Lincoln, K. D., Chatters, L. M., \& Taylor, R. J. (2003). Psychological distress among black and white Americans: Differential effects of social support, negative interaction, and personal control. Journal of Health and Social Behavior, 44 (3), $390-407$.

Magnusson, K. A., \& Duncan, G. J. (2002). Parents in poverty. In M. H. Bornstein (Ed.), 
Handbook of parenting ( $2^{\text {nd }}$ ed., pp. 95-121). Mahwah, NJ: Erlbaum.

Mayer, S. (1997). What money can't buy. Cambridge, MA: Harvard University Press.

McGill-Franzen, A., Lanford, C., \& Adams, E. (2002). Learning to be literate: A comparison of five urban early childhood programs. Journal of Educational Psychology, 94 (3), 445-464.

McLoyd, V. C. (1998). Socioeconomic disadvantage and child development. American Psychologist, 53, 185-204.

McLoyd, V. C., \& Wilson, L. (1990). Maternal behavior, social support, and economic conditions as predictors of distress in children. New Directions for Child Development, 46, 49-69.

Meyers, A. F., Karp, R. J., \& Kral, J. G. (2006). Poverty, food insecurity, and obesity in children. Pediatrics, 118, 2265a-2266.

Miller, D. C., \& Byrnes, J. P. (2001). Adolescents' decision-making in social situations: A self-regulation perspective. Applied Developmental Psychology, 22, 237-256.

Mistry, R. S., Biesanz, J., Taylor, L. C., Burchinal, M., and Cox, M. J. (2004). Family income and its relation to preschool children's adjustment for families in the NICHD study of early child care. Developmental Psychology, 40, (5), 727-745.

Mistry, R. S., Lowe, E. D., Benner, A. D., \& Chien, N. (2008). Expanding the family economic stress model: Insights from a mixed-models approach. Journal of Marriage and Family, 70, 196-209.

Mistry, R. S., Benner, A. D., Biesanz, J., Clark, S., \& Howes, C. (in press). Family and social risk, and parental investments during the early childhood years as predictors of low-income children's school readiness outcomes. Early Childhood Research Quarterly. 
Mitchell, C. E. (1989). Internal locus of control for expectation, perception and management of answered prayer. Journal of Psychology and Theology, 17 (1), 2126.

Nnakwe, N. E. (2008). Dietary patterns and prevalence of food insecurity among lowincome families participating in community food assistance programs in a midwest town. Family and Consumer Sciences Research Journal, 36 (3), 229242.

Olson, C. M., Bove, C. F., \& Miller, E. O. (2007). Growing up poor: Long-term implications for eating patterns and body weight. Appetite, 49, 198-207.

Reijneveld, S. A., Veenstra, R., de Winter, A. F., Verhlst, F. C., Ormel, J., \& de Meer, G. (2010). Area deprivation affects behavioral problems of young adolescents in mixed urban and rural areas: The TRAILS study. Journal of Adolescent Health, $46,189-196$.

Rotter, J. B. (1954). Social learning and clinical psychology. Englewood Cliffs, NJ: Prentice-Hall.

Rotter, J. B. (1966). Generalized expectancies for internal versus external control of reinforcement. Psychological Monographs: General and Applied, 1.

Rotter, J. B. (1975). Some problems and misconceptions related to the construct of internal versus external control of reinforcement. Journal of Counseling and Clinical Psychology, 43 (1), 55-67.

Rubinton, N. (1980). Instruction in career decision making and decision-making styles. Journal of Counseling Psychology, 27 (6), 581-588.

Scott, S. G., \& Bruce, R. A. (1995). Decision-making style: The development and assessment of a new measure. Educational and Psychological Measurement, 55 
(5), 818-831,

Seccombe, K (2000). Families in poverty in the 1990s: Trends, causes, consequences, and lessons learned. Journal of Marriage and the Family, 62 (4), 1094-1113.

Shek, D. T. L. (2005). Economic stress, emotional quality of life, and problem behavior in Chinese adolescents with and without economic disadvantage. Social Indicators Research, 71 (1/3), 363-383.

Spicer, D. P., \& Sadler-Smith, E. (2005). An examination of the general decision making style in two U. K. samples. Journal of Mangerial Psychology, 20 (1/2), 137-149.

Taylor, Z. E., Widaman, K. F., Robins, R. W., Jochem, R., Early, D. R., \& Conger, R. D. (2012). Dispositional optimism: A psychological resource for Mexican-origin mothers experiencing economic stress. Journal of Family Psychology, 26 (1), 133-139.

Thompson, S. C., Nierman, A., Schlehofer, M. M., Carter, E., Bovin, M. J., Wurzman, L., Tauber, P., Trifskin, S., Marks, P., Sumner, J., Jackson, A., \& Vonasch, A. (2007). How do we judge personal control? Unconfounding contingency and reinforcement in control judgments. Basic and Applied Social Psychology, 29 (1), $75-84$

Thunholm, P. (2004). Decision-making: Habit, style, or both? Personality and Individual Differences, $36(4), 931-944$.

Thunholm, P. (2008). Decision-making styles and physiological correlates of negative stress: Is there a relation? Scandinavian Journal of Psychology, 49, 213-219.

Thunholm, P. (2009). Military leaders and followers- do they have different decision styles? Scandinavian Journal of Psychology, 50, 317-324.

Whelan, C. T., \& Maitre, B. (2007). Income, deprivation, and economic stress in the 
enlarged European Union. Social Indicators Research, 83, 309-329.

Wu, Z., \& Schimmele, C. M. (2006). Food insufficiency and depression. Sociological Perspectives, 48 (4), 481-504.

Zaslow, M., Bronte-Tinkew, J., Capps, R., Horowitz, A., Moore, K. A., \& Weinstein, D. (2009). Food security during infancy: Implications for attachment and mental proficiency in toddlerhood. Maternal and Child Health Journal, 13, 66-80. 